\title{
Physicochemical, Sensory and Microbiological Quality of Table Wine Produced from Coconut water, Honey and Zobo
}

\author{
C. O. Ajogun, S. C. Achinewhu, D. B. Kiin-Kabari and O. M. Akusu
}

\begin{abstract}
Physicochemical, sensory and microbiological quality of table wine produced from coconut, water, honey and zobo. Coconut water was collected and mixed with Zobo at a ratio of 5:1 and with honey also at 5:1 ratio. The various mixtures were fermented with wine yeast at room temperature $\left(28 \pm 2{ }^{\circ} \mathrm{C}\right)$ for 7 days to produce table wine. There was no significant difference $(\mathbf{P}>\mathbf{0 . 0 5})$ in the fat, protein, ash and Carbohydrate content of all the wine samples, including control (commercial red and white table wines). Total Acid and alcohol content ranged from $0.576-0.921 \%$ and $5.87-11.50 \%$, respectively. Sugar content ranging from 11.00-12.00\%, however, difference in sugar content of all the wine samples were not statistically significant $(P>0.05)$. The specific gravity of the coconut wines was significantly $(P<0.05)$ higher than those of the control (commercial red and white wine). Total yeast count (TYC) on the fresh wine after 7 days' fermentation period ranging from $7.66 \log _{10} \mathrm{CFU} / \mathrm{ml}$ to $8.91 \log _{10} \mathrm{CFU} / \mathrm{ml}$, with sample CWHN (coconut water and honey wine without yeast $)$ given significantly $(P<0.05)$ higher value of 8.91 $\log _{10} C F U / m l$. Total bacteria count (TBC) on the aged wine (after 21 days of storage) ranged from $5.145 \log _{10}$ CFU/ml to 6.230 $\log _{10} \mathrm{CFU} / \mathrm{ml}$ with sample CWH (coconut water and honey) wine given significantly higher value of 6.23 $\log _{10} \mathrm{CFU} / \mathrm{ml}$. The taste of sample CWZ compared favourably with those of the commercial red and white wines. Sample CWZ (coconut/zobo wine) received equal overall acceptability with the commercial table wines.
\end{abstract}

Index Terms - Fermentation, Wine, Coconut, Zobo, Honey, Physicochemical, Microbiological, Sensory.

\section{INTRODUCTION}

Fermented beverages and alcoholic drinks are culturally and socially accepted products for consumption, drinking, entertainment, customary practices, and religious purposes. Across the globe (Europe, America, Australia, Asia, and recently, Africa), winemaking processes are popular [1]-[2]. Wine, an alcoholic beverage is produced from the fermentation of fruit juices especially grape which have a chemical balance that allows them to ferment without addition of sugar, acids, enzymes or other nutrients [3]. Many tropical and subtropical fruits, including grapes, apples, pears, apricots, berries, peaches, sugar cane, oranges, mangoes, bananas and pineapples yield good amounts of juice on extraction [3]-[4]. Upon fermentation, fruit juices

Published on September 26, 2020.

C. O. Ajogun, Rivers State University, Nigeria.

S. C. Achinewhu, Rivers State University, Nigeria.

D. B. Kiin-Kabari, Rivers State University, Nigeria.

(corresponding e-mail: kabaridavid@yahoo.com)

O. M. Akusu, Rivers State University, Nigeria. can be changed into wines [5]-[7]. Different varieties of grapes and strains of yeasts produce different types of wine. These variations result from the complex interactions between the biochemical components of the grape, the reactions involved in fermentation and the overal production process [8].

Wines are classified as natural wines having an alcoholic content of $9-14 \%$ and dessert and appetizer wines with alcohol content $15-21 \%$. Wine can also be categorized as sweet or dry depending on the conditions during alcoholic fermentation. The subjective sweetness of a wine is determined by the interaction of several factors, including the amount of sugar in the wine, but also the relative levels of alcohol, acids and tannins. The most famous types of wines are red and white wines, followed by rosé and sparkling wines. Table wines are dry if sugar content is $0.3 \%$ and alcohol $9-14 \%$, semi-dry with sugar content of $0.5-3 \%$ and alcohol $12.9 \%$ and sweet with sugar 3-8\% and alcohol $12.9 \%$ [9].

Coconut water is liquid endosperm, which formed gradually as from the third month of coconut maturation and reaching a maximum in eight months, declining as the nut ripens [10]. It is a faintly turbid to clear liquid, colourless, sweet, naturally flavoured and slightly acidic with reported $\mathrm{pH}$ ranging from 4.2 to 6.0 [11]. Coconut water is largely consumed all over the world, not only as a refreshing drink, but also because of its numerous therapeutic qualities. Coconut water has high mineral content such as potassium, sodium, chlorides, magnesium and phosphorus. It contents some high level of vitamins like vitamins B and ascorbic acid [12]. This high mineral and sugar content of coconut water makes it to be considered as sports drink. It is sweet drink that is sterile in its natural form and rich in amino acids like arginine, alanine, and cystine. It is used as oral rehydration fluid for elderly people and children suffering from gastroenteritis [13]. Coconut water contain cytokinis which contributes to some health benefits such as anticarcinogenic, anti-aging and anti-thrombotic [14]. Coconut water obtained from mature nuts, when harvested for the production of copra and coconut oil, is wasted on a large scale in several tropical countries.

Honey is a sweet (mostly consisting of monosaccharides of fructose and glucose) jelly-like substance made from the nectar of flowers by bees. The high sugar content present in honey predisposes it as a good substrate for yeast fermentation to produce alcohol and carbon dioxide gas. Honey wines have ancient history in Asia and were regarded 
as the beverage for the nobles and gods, for spiritual wisdom and life [15].

Roselle (Hibiscus sabdariffa L.) is a commonly grown plant and is extensively grown in Nigeria, particularly in the country's North-Eastern and middle belt areas [16]. It is herb of economic importance as it can serve as a source of essential minerals and vitamins such as riboflavin, niacin, calcium and iron [17]. The zobo drink has demonstrated its immense potential to be great source of carbohydrate, vitamin $\mathrm{C}$ and protein which is the significant reasons for drinking juice [18].

In spite of the numerous advantages of coconut water, zobo and honey, diversity in their application is still limited in Nigeria. The use of coconut water in Nigeria is very limited and most time wasted when coconut is used for other purposes. Thus, the objective of this work was to monitor and evaluate the changes in physicochemical properties and microbiological quality of coconut ( $\operatorname{Cocos}$ nucifera L) water, honey and zobo 'must' during fermentation, in wine production.

\section{MATERIALS AND METHODS}

Mature Coconut fruits, wine yeast, sugar, honey and zobo (Roselle Calyx) were procured from Oil Mill Port Harcourt, Rivers State, Nigeria, and transported to Rivers Stater University.

\section{A. Preparation of Coconut Wine}

Mature coconut was unshelled, the water collected and mixed with honey and zobo for wine production, as illustrated in Fig. 1.

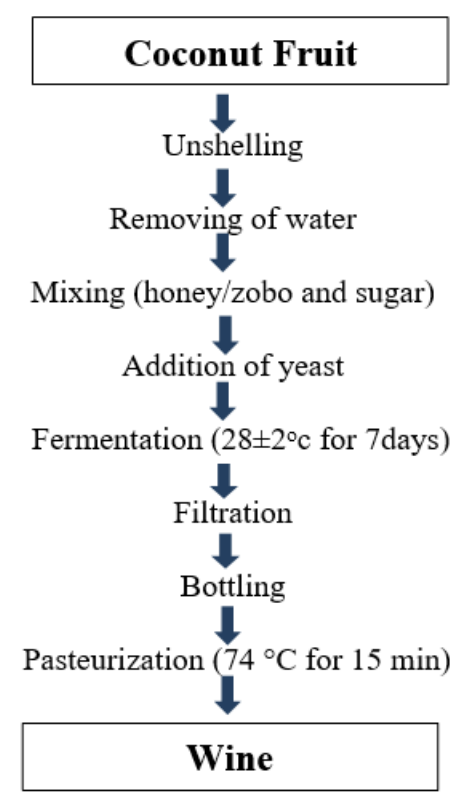

Fig. 1. Production of Table Wine from Coconut Water, Zobo and Honey.

\section{B. Inoculum development}

Cells suspension of commercial wine yeast developed by inoculating into $250 \mathrm{ml}$ of YEPG broth $(20 \mathrm{~g} / \mathrm{l}$ glucose; $10 \mathrm{~g} / \mathrm{l}$ yeast extract; $10 \mathrm{~g} / \mathrm{l}$ peptone) in $500 \mathrm{ml}$ conical flask, aerated by shaking on shaker and incubated at $28-30{ }^{\circ} \mathrm{C}$ for
4 days, then pitched inoculum developed into the fermenter containing the must [19].

\section{Preparation of "Must"}

"Must" preparation was carried out according to the method of [20]. Dried zobo calyces (300 gram) extract was obtained by boiling in $2000 \mathrm{ml}$, the extract separated from the calyces and stored in the refrigerator. Coconut water was obtained by carefully cracking the nut, not allowing spill. Metabisulphite $0.2 \mathrm{~g}$ was added to the coconut water. Coconut-zobo blend was mixed in the ratio of $5: 1$ to obtain $3000 \mathrm{ml}$. The 'must' (coconut-zobo blend) was chaptalized up to $22 \%(\mathrm{w} / \mathrm{v})$ brix by adding granulated sucrose (240 $\mathrm{g} / \mathrm{l}$ ), while Coconut-honey blend was prepared by adding $500 \mathrm{ml}$ of honey to $2500 \mathrm{ml}$ of coconut water. Ammonium sulphate $2.53 \mathrm{~g} / \mathrm{l}$; potassium dihydrogen phosphate $1.3 \mathrm{~g} / \mathrm{l}$; yeast extract $0.1 \mathrm{~g} / 1$ and magnesium sulphate hydrate $0.1 \mathrm{~g} / \mathrm{l}$ for supplementation. Two hundred milliliters of the propagated yeast cells at $10^{8}$ cells were pitched into the 'must'.

\section{Fermentation Process}

Primary Fermentation; Fermentation of musts were carried out in 10 liters containers at room temperature $\left(28 \pm 2{ }^{\circ} \mathrm{C}\right)$. All the treatments (coconut water 'must', coconut water-honey 'must', coconut water-zobo 'must' and coconut water-honey without yeas 'must'. were allowed to ferment for 6 days. Aliquot of the musts obtained were used for physiochemical and microbiological analysis. During this period, microbial analysis, sugar content, specific gravity and $\mathrm{pH}$ of the 'must' was monitored on daily basis.

Secondary Fermentation: After the primary fermentation, an air tap was fixed to the fermenting vessel to indicate the end of primary fermentation. Secondary fermentation was terminated after 7 days and then the wine was filtered. The microbial analysis sugar content, specific gravity, titratable acidity and $\mathrm{pH}$ of the wine was monitored at the end of the secondary fermentation.

Clarification and Racking: After secondary fermentation, the wine was racked weekly for 3 weeks to clear the wine.

Aging: After the racking, the wine was kept in the refrigerator for maturation (2 weeks) and then packaged, pasteurized and stored for further analysis.

\section{E. Proximate Composition of Wine}

Proximate Composition, including moisture, fat, ash, protein and carbohydrate was determined using standard methods [21].

\section{F. Specific Gravity of Wine produced from Coconut water, Zobo and Horney}

Using standard method [21]. Fifty $\mathrm{ml}$ specific gravity bottle was thoroughly cleaned with distilled water, dried in an oven for $50{ }^{\circ} \mathrm{C}$ allowed to cool. The weight of the cooled dried bottle (W1) was recorded. The dried bottle was filled with deionized water and surface of the bottle was cleaned with a cotton wool and weighed as (W2). The bottle was empty and cleaned twice with $10 \mathrm{ml}$ of the 'must' thereafter the bottle was filled to the brim with the 'must' and the bottle cleaned with cotton wool and weighed as (W3). This was done at 24 hours' interval of 7 days' fermentation period. The specific gravity (S.G) was calculated. 


$$
\mathrm{S} . \mathrm{G}=\frac{W 3-W 2}{W 2-W 1}=\frac{S}{W}
$$

where

$\mathrm{S}=$ weight of volume of 'must' $\left(\mathrm{w}_{3}-\mathrm{w}_{1}\right)$

$\mathrm{W}=$ weight of volume of water $\left(\mathrm{w}_{2}-\mathrm{w}_{1}\right)$

G. Alcohol content of Wine produced from Coconut water, Zobo and Horney

The alcohol content of the wine was determined using specific gravity as described by [22], and calculated as follows:

Percentage alcohol $=(\mathrm{OG}-\mathrm{FG}) \times 131.25$

where:

$\mathrm{OG}=$ Original Gravity of the sample.

FG $=$ Final Gravity of the sample.

$131.25=$ constant based on the absolute weight of pure water and ethanol.

\section{H. Microbial monitoring and analysis}

All the media used are $\mathrm{TM}^{\circledR}$ media and prepared in accordance with the manufacturer's instruction: Nutrient agar 28 g/l; MacConkey agar 52 g/l; Potato Dextrose Agar $39 \mathrm{~g} / \mathrm{l}$ and de Man Rogosa and Sharpe agar $66.73 \mathrm{~g} / \mathrm{l}$. Tenfold serial dilution of each sample was carried out, 0.1 $\mathrm{ml}$ volume was plated out from $10^{-6}$ dilution factor and spread on solid agar plate, incubated at ambient temperature for 48 hours.

\section{Total Bacteria count (TBC)}

The microbiological analysis was carried out according to methods described by [23]. Plate count agar was used for enumeration of bacteria. A well homogenized sample was serially diluted with $0.1 \%$ peptone water up to $10^{-6}$. One $\mathrm{ml}$ aliquot from a suitable dilution was transferred aseptically into sterile petri dishes. To each plate about $15 \mathrm{ml}$ of melted and cooled nutrient agar was added. The inoculate was evenly mixed with media by rotating the plates and allowed to solidify. The inverted plate was incubated for 48hours. The TBC (cfu/ml) was determined using a colony counter.

\section{J. Yeast and Mould Enumeration}

Potato dextrose agar (PDA) was used for enumeration of yeast and mould. Well homogenized samples were serially diluted with $0.1 \%$ pepetone water up to $10^{-6}$. Aliquots $(0.1 \mathrm{ml})$ from a suitable dilution were transferred aseptically into solidified PDA plates. Samples were spread all over the surface of the plates using sterile bent glass rod. The plates were then incubated for $72 \mathrm{hrs}$ at $28{ }^{\circ} \mathrm{C}$. Counting (cfu/ml) were carried out by using colony counter [23].

\section{K. Total Coliform Test}

The total coliform test was carried out by multiple tube techniques according to [24]. One (1g) of wine sample was diluted in $9 \mathrm{ml}$ distilled water. A serial dilution was then prepared up to $10^{-3}$. The sample was cultured in MacConkey agar and incubated at $37^{\circ} \mathrm{C}$ for $48 \mathrm{hrs}$.

\section{Sensory Evaluation}

The sensory evaluation of the wine was carried out by 20 semi trained panelists from students and staff of the department of Food Science and Technology, Rivers State
University, Port Harcourt. Samples were scored for taste, aroma, colour, clarity and overall acceptability using a 9point hedonic scale according to the method of [25]. commercial wine was used as control.

\section{Statistical Analysis}

All the analyses were carried out in triplicate. Data obtained were subjected to Analysis of variance (ANOVA), differences between means were evaluated using Tukey's multiple comparison test, and significance accepted at $\mathrm{P} \leq$ 0.05 level. The statistical package in Minitab 16 computer program was used.

\section{RESULTS AND DISCUSSION}

\section{A. Changes in Specific Gravity (SG) of} Coconut/Honey/Zobo 'Must' During Fermentation

Result for physicochemical properties of "must" from coconut water/honey/zobo mixture showed that Specific Gravity of the "must" reduced significantly with fermentation time (Fig. 2). These could be due to increased metabolic activities leading to exhaustion of available nutrients with the concomitant production of alcohol, which has lower SG [26]. The specific gravity (SG) of must from coconut water without yeast, reduced significantly $(\mathrm{P}<0.05)$ from 1.157 on day one of fermentation to 1.0168 on day six. For sample CW (coconut water), the SG was constant up to day 3 and reduced significantly to 0.961 on day 4,5 , and 6 . SG of sample CWZ (coconut water and zobo) reduced from 1.1763 on day 1 to 1.0382 on day 2 and remained relatively constant to the sixth day of fermentation. Reduction in specific gravity of coconut must during fermentation from 1.015 to 0.886 had earlier been reported by [27]. Awe [28] also reported reduction in SG of pawpaw must from 1.060 to 0.996 during fermentation.

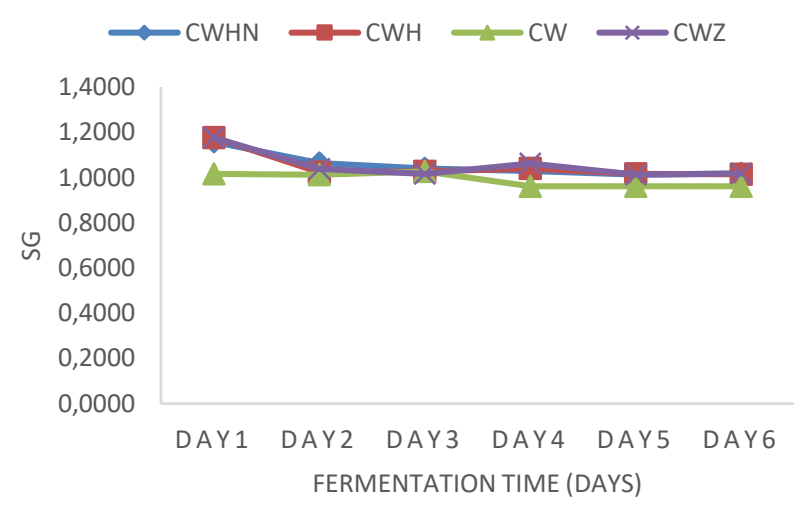

Fig. 2. Changes in Specific Gravity (SG) of Coconut/Honey/Zobo Must During Fermentation.

Key: $\mathrm{CWZ}=$ coconut water and zobo, $\mathrm{CW}=$ coconut water, $\mathrm{CWH}=$ coconut water and honey, $\mathrm{CWHN}=$ coconut water and honey (no yeast).

\section{B. Changes in pH of Coconut/Honey/Zobo 'Must' During Fermentation}

$\mathrm{pH}$ of "must" from coconut water $(\mathrm{CW})$ reduced from 4.90 on day one to 2.40 on day 3 and remained constant up to day 6 (Fig. 3). pH of sample CWHN (coconut water and honey without yeast) reduced from 4.35 to 3.20 after six days of fermentation. $\mathrm{pH}$ of sample $\mathrm{CWH}$ was relatively 
constant from day 1 to day 2 and reduced significantly $(\mathrm{P}<0.05)$ to 3.05 on day 6 . The drop in $\mathrm{pH}$ and corresponding increase in titratable acidity of must during aerobic and anaerobic fermentation stages are attributable to yeast metabolism. These also showed acidification of the medium as fermentation progresses, which is crucial to wine production. Acidity plays a vital role in determining wine quality by aiding the fermentation process and enhancing the overall characteristics and balance of the wine. Lack of acidity will mean a poor fermentation [29]. Low $\mathrm{pH}$ is known to give yeast comparative advantage in natural environments. A similar observation has been reported by [30] in their study on Mixed Fruits (Pineapple and Watermelon). Ogodo et al. [31] also reported decrease in $\mathrm{pH}$ and an increase in acidity during production of mixed fruit wines of pawpaw, banana and watermelon. The present report is also consistent with the report of other researcher for some tropical fruit wines such as tundu [32], sweet potato [33] and banana [34]. The decrease in $\mathrm{pH}$ and an increase in acidity could be attributed to production and accumulation of organic acids during fermentation

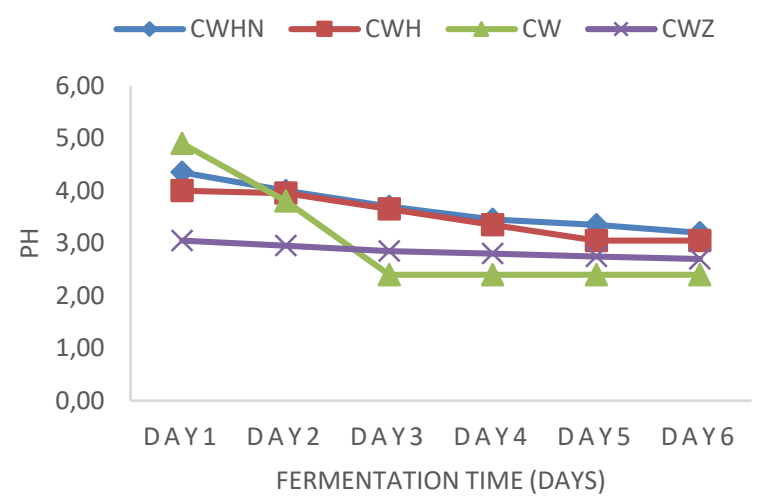

Fig. 2. Changes in $\mathrm{pH}$ of Coconut, Honey and Zobo Must During Fermentation.

Key: $\mathrm{CWZ}=$ coconut water and zobo, $\mathrm{CW}=$ coconut water, $\mathrm{CWH}=$ coconut water and honey, $\mathrm{CWHN}=$ coconut water and honey no yeast.

\section{Changes in Percentage Sugar Content (Brix) of Coconut Wine during Fermentation}

From the result in Fig. 4, the sugar content of the 'must' all decreased after 6 days of fermentation. Sample CW decreased from $21.00 \%$ to $9.00 \%$. Sugar content of "must" from coconut water and zobo (CWZ) reduced from $17.20 \%$ to $8.00 \%$, samples CWHN reduced from $13.50 \%$ to $9.00 \%$, while sample $\mathrm{CWH}$ experience a rapid decreased on day 1 $9.5 \%$ and became constant from day 3 to day $48.0 \%$ of fermentation. This result agreed with the reports of [6] who observed a decrease in the sugar content of overripe mango wine.

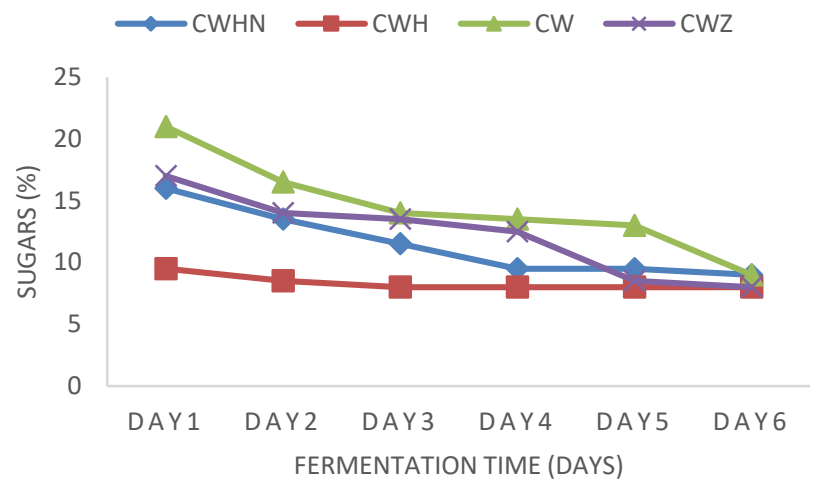

Fig. 4. Changes in Percentage Sugar Content (Brix) of Coconut/Honey/Zobo Must During Fermentation.

Key: $\mathrm{CWZ}=$ coconut water and zobo, $\mathrm{CW}=$ coconut water, $\mathrm{CWH}=$ coconut water and honey, $\mathrm{CWHN}=$ coconut water and honey without yeast.

\section{Total Yeast Count (Log10 CFU/ml) of Coconut/Honey/Zobo 'Must' during Fermentation}

As shown in Table 1, the yeast count ranged from 7.45 to $7.66 \log _{10} \mathrm{CFU} / \mathrm{ml}, 7.66$ to $8.84 \log _{10} \mathrm{CFU} / \mathrm{ml}, 8.56-8.98$ $\log _{10} \mathrm{CFU} / \mathrm{ml}$ and $6.60-8.08 \log _{10} \mathrm{CFU} / \mathrm{ml}$, for samples $\mathrm{CWZ}, \mathrm{CWH}, \mathrm{CWHN}$ and $\mathrm{CW}$ respectively. There was significant $(\mathrm{P}>0.05)$ change in the yeast count of sample CWZ on day 2 of fermentation. The Total yeast count of sample $\mathrm{CWH}$ and $\mathrm{CW}$ were constant from day 2 to 5 , but decreased significant $(\mathrm{P}<0.05)$ on the sixth day of fermentation to $8.19 \log _{10} \mathrm{CFU} / \mathrm{ml}$ for sample $\mathrm{CWH}$ and increased significant $(\mathrm{P}<0.05)$ on sixth day of fermentation to $8.08 \log _{10} \mathrm{CFU} / \mathrm{ml}$, for sample $\mathrm{CW}$. The increase in the total yeast count during fermentation can be attributed to the presence of utilizable sugar (sucrose) and yeast nutrient. The daily aeration of the fermenting must also have aided rapid multiplication of the yeast cells [29]-[35].

TABLE 1: TOTAL YEAST COUNT ( $\left.\mathrm{LOG}_{10} \mathrm{CFU} / \mathrm{ML}\right)$ OF COCONUT/HONEY/ZOBO 'MUST' DURING FERMENTATION

\begin{tabular}{ccccc}
\multicolumn{5}{c}{ COCONUT/HONEY/ZOBO 'MUST' DURING FERMENTATION } \\
\hline Fermentation & \multirow{5}{c}{ CWZ } & CWH & CWHN & CW \\
Time & $7.57^{\mathrm{ab}}$ & $7.66^{\mathrm{c}}$ & $8.85^{\mathrm{c}}$ & $6.6^{\mathrm{c}}$ \\
\hline \multirow{2}{*}{ Day1 } & \pm 0.082 & \pm 0.017 & \pm 0.017 & \pm 0.000 \\
& $7.45^{\mathrm{b}}$ & $8.84^{\mathrm{a}}$ & $8.92^{\mathrm{ab}}$ & $7.61^{\mathrm{b}}$ \\
Day2 & \pm 0.002 & \pm 0.045 & \pm 0.011 & \pm 0.015 \\
& $7.65^{\mathrm{a}}$ & $8.81^{\mathrm{a}}$ & $8.56^{\mathrm{e}}$ & $7.82^{\mathrm{b}}$ \\
Day3 & \pm 0.006 & \pm 0.001 & \pm 0.031 & \pm 0.028 \\
& $7.62^{\mathrm{a}}$ & $8.67^{\mathrm{a}}$ & $8.98^{\mathrm{a}}$ & $7.84^{\mathrm{b}}$ \\
Day4 & \pm 0.014 & \pm 0.148 & \pm 0.006 & \pm 0.027 \\
& $7.64^{\mathrm{a}}$ & $8.42^{\mathrm{ab}}$ & $8.74^{\mathrm{d}}$ & $7.73^{\mathrm{b}}$ \\
Day5 & \pm 0.006 & \pm 0.163 & \pm 0.006 & \pm 0.136 \\
& $7.66^{\mathrm{a}}$ & $8.19^{\mathrm{b}}$ & $8.91^{\mathrm{bc}}$ & $8.08^{\mathrm{a}}$ \\
Day6 & \pm 0.013 & \pm 0.157 & \pm 0.011 & \pm 0.010 \\
\hline
\end{tabular}

Values are means \pm standard deviation of duplicate samples.

Mean values bearing different superscript in the same column differ significantly $(\mathrm{P}<0.05)$

Key: $\mathrm{CWZ}=$ coconut water and zobo, $\mathrm{CW}=$ coconut water, $\mathrm{CWH}=$ coconut water and honey, $\mathrm{CWHN}=$ coconut water and honey without yeast.

\section{E. Total Coliform Count $(\log 10 \quad \mathrm{CFU} / \mathrm{ml})$ of Coconut/Honey/Zobo 'Must' during Fermentation}

No coliform growth was seen in samples CWZ and CW 'Must' throughout the period of fermentation (Table 2). No growth was also observed in the first and fort day for sample CWH Must, while the Total coliform count (TCC) of 7.92, 7.48, 7.30 and 7.00 $\log _{10} \mathrm{CFU} / \mathrm{ml}$ shown on days 2,3,5 and 6 where not statistically different $(\mathrm{P}>0.05)$. Lower microbial 
count of the wine may specifically be as a result of the presence of alcohol, organic acids and increase in total acidity. low $\mathrm{pH}$ inhibits pathogenic and putrefactive bacterial activity, thus affecting bacterial growth and metabolism [36]-[38]. Total coliform of $8.09 \log _{10} \mathrm{CFU} / \mathrm{ml}$ to $7.78 \log _{10} \mathrm{CFU} / \mathrm{ml}$ was seen in sample CWHN from day one to six, these values however, showed significant $(\mathrm{P}<0.05)$ drop on day 4 and 5 to $7.00 \log _{10} \mathrm{CFU} / \mathrm{ml}$. the presence of coliforms generally signifies poor sanitary condition. The ICMSF [39] recommended absence of coliform in wines.

TABLE 2: TOTAL COLIFORM COUNT ( $\mathrm{LOG}_{10} \mathrm{CFU} / \mathrm{ML}$ ) OF COCONUT/HONEY/ZOBO 'MUST' DURING FERMENTATION

\begin{tabular}{ccrrl}
\hline \multicolumn{1}{c}{$\begin{array}{c}\text { Samples } \\
\text { Time }\end{array}$} & CWZ & \multicolumn{1}{l}{ CWH } & CWHN & CW \\
\hline Day1 & NG & NG & $8.09^{\mathrm{a}} \pm 0.125$ & NG \\
Day2 & NG & $7.92^{\mathrm{a}} \pm 0.879$ & $8.19^{\mathrm{a}} \pm 0.020$ & $\mathrm{NG}$ \\
Day3 & $\mathrm{NG}$ & $7.48^{\mathrm{a}} \pm 0.000$ & $7.87^{\mathrm{a}} \pm 0.041$ & $\mathrm{NG}$ \\
Day4 & $\mathrm{NG}$ & $\mathrm{NG}$ & $7.00^{\mathrm{b}} \pm 0.000$ & $\mathrm{NG}$ \\
Day5 & $\mathrm{NG}$ & $7.30^{\mathrm{a}} \pm 0.426$ & $7.00^{\mathrm{b}} \pm 0.000$ & $\mathrm{NG}$ \\
Day6 & $\mathrm{NG}$ & $7.00^{\mathrm{a}} \pm 0.000$ & $7.78^{\mathrm{a}} \pm 0.249$ & $\mathrm{NG}$ \\
\hline
\end{tabular}

Values are means \pm standard deviation of duplicate samples.

Mean values bearing different superscript in the same column differ significantly $(\mathrm{P}<0.05)$.

Key: $\mathrm{CWZ}=$ coconut water and zobo, $\mathrm{CW}=$ coconut water, $\mathrm{CWH}=$ coconut water and honey, $\mathrm{CWHN}=$ coconut water and honey without yeast, $\mathrm{NG}=$ No growth.

\section{F. Total Bacteria Count (Log10 CFU/ml) of Coconut/Honey/Zobo 'Must' during Fermentation}

From the result, no growth (NG) was noticed in samples CWZ and CW (Table 3). Bacteria growth noticed on both samples CWH and CWHN could be from the honey use in chaptalization. From the result of samples $\mathrm{CWH}$ and $\mathrm{CWHN}$ as the fermentation progresses the bacterial growth was also reducing. Inhibition of bacterial growth is probably due to alcohol production. Alcohol inhibits bacterial growth by plasmolyzing bacterial cell walls [40]. The TBC of sample CWHN reduced significantly $(\mathrm{P}<0.05)$ from $8.87 \log 10$ $\mathrm{CFU} / \mathrm{ml}$ on day 1 to $7.76 \mathrm{Log} 10 \mathrm{CFU} / \mathrm{ml}$ after six days of fermentation. Reduction in TBC of samples $\mathrm{CWH}$ and CWHN could also be due to reduction in $\mathrm{pH}$ and increase in Total titrable acidity.

TABLE 3: TOTAL BACTERIA COUNT (LOG10 CFU/ML) OF COCONUT/HONEY/ZOBO 'MUST' DURING FERMENTATION

\begin{tabular}{|c|c|c|c|c|}
\hline \multicolumn{5}{|c|}{ Samples } \\
\hline $\begin{array}{c}\text { Fermentation } \\
\text { Time }\end{array}$ & CWZ & CWH & CWHN & CW \\
\hline Day1 & NG & NG & $8.87^{\mathrm{a}} \pm 0.004$ & NG \\
\hline Day2 & NG & NG & $8.14^{b c} \pm 0.197$ & NG \\
\hline Day3 & NG & NG & $8.26^{\mathrm{b}} \pm 0.000$ & NG \\
\hline Day4 & NG & $8.720^{\mathrm{a}} \pm 0.018$ & $8.16^{\mathrm{b}} \pm 0.021$ & NG \\
\hline Day5 & NG & $7.70^{\mathrm{b}} \pm 0.000$ & $7.78^{\mathrm{cd}} \pm 0.000$ & NG \\
\hline Day6 & NG & $7.500^{\mathrm{b}} \pm 0.281$ & $7.76^{\mathrm{d}} \pm 0.116$ & NG \\
\hline
\end{tabular}

Values are means \pm standard deviation of duplicate samples.

Mean values bearing different superscript in the same column differ significantly $(\mathrm{P}<0.05)$.

Key: $\mathrm{CWZ}=$ coconut water and zobo, $\mathrm{CW}=$ coconut water, $\mathrm{CWH}=$ coconut water and honey, $\mathrm{CWHN}=$ coconut water and honey without yeast, $\mathrm{NG}=$ No growth.
G. Proximate Composition of Aged Table Wine Produced from Coconut Water and its Blends with Zobo and Honey

The results of the proximate composition (Table 4) showed level of significance between the moisture content only. The moisture, fat, protein, ash and Carbohydrate content ranged from $93.90 \%-95.986 \%, 1.479-2.435 \%$, $0.657-1.532 \%, 0.225-0.748 \%$ and $1.093-2.968 \%$, respectively. Moisture content of the control Red wine (RW) and sample $\mathrm{CW}$ (coconut water wine) were significantly $(\mathrm{P}<0.05)$ higher. There was no significant difference $(\mathrm{P}>0.05)$ in the fat, protein, ash and Carbohydrate content of all the wine samples, including control (red and white wines). High moisture content makes beverage suitable as a refreshing and quench- thirsting product which is a characteristic of good beverage. This is similar to the report given by [30]. A minimal amount of ash was obtained. This indicates the presence of mineral component in the wine. This was in agreement with earlier reports of $0.5 \%$ ash in wine made from fruit juices [41]. Low fat content suggests that the wines could provide protection against excess body lipids (cholesterol) and it also demonstrate the desirable nutritive quality of fruit wine as reported by [28]. Low protein content of the wines offers suitability for maintenance of cellular organization, as reported by [42]. A decrease in the carbohydrate content of the wine was observed. This might be due to decline in the sugar content as a result of rapid and effective utilization of the sugar available in the must by the yeast cells leading to the fermentation of the must [43].

Table 4. Proximate Composition of Aged Table Wine Produced FROM COCONUT WATER AND ITS BLENDS WITH ZOBO AND HONEY.

\begin{tabular}{cccccc} 
Samples & $\begin{array}{c}\text { Moisture } \\
(\%)\end{array}$ & $\begin{array}{c}\text { Fat } \\
(\%)\end{array}$ & $\begin{array}{c}\text { Protein } \\
(\%)\end{array}$ & $\begin{array}{c}\text { Ash } \\
(\%)\end{array}$ & $\begin{array}{c}\text { Cho } \\
(\%)\end{array}$ \\
\hline \multirow{2}{*}{ CWHN } & $93.941^{\mathrm{b}}$ & $2.244^{\mathrm{a}}$ & $0.863^{\mathrm{a}}$ & $0.748^{\mathrm{a}}$ & $2.205^{\mathrm{a}}$ \\
& \pm 0.052 & \pm 0.412 & \pm 0.000 & \pm 0.422 & \pm 0.041 \\
CWH & $94.723^{\mathrm{b}}$ & $2.435^{\mathrm{a}}$ & $1.327^{\mathrm{a}}$ & $0.424^{\mathrm{a}}$ & $1.093^{\mathrm{a}}$ \\
& \pm 0.013 & \pm 0.034 & \pm 0.302 & \pm 0.106 & \pm 0.173 \\
RW & $95.986^{\mathrm{a}}$ & $1.479^{\mathrm{a}}$ & $0.657^{\mathrm{a}}$ & $0.225^{\mathrm{a}}$ & $1.655^{\mathrm{a}}$ \\
& \pm 0.169 & \pm 0.288 & \pm 0.292 & \pm 0.036 & \pm 0.786 \\
WW & $95.811^{\mathrm{ab}}$ & $1.962^{\mathrm{a}}$ & $0.638^{\mathrm{a}}$ & $0.342^{\mathrm{a}}$ & $2.968^{\mathrm{a}}$ \\
& \pm 0.738 & \pm 0.148 & \pm 0.000 & \pm 0.210 & \pm 1.430 \\
CW & $95.953^{\mathrm{a}}$ & $1.801^{\mathrm{a}}$ & $1.532^{\mathrm{a}}$ & $0.424^{\mathrm{a}}$ & $1.610^{\mathrm{a}}$ \\
& \pm 0.878 & \pm 0.016 & \pm 0.301 & \pm 0.177 & \pm 0.849 \\
CWZ & $93.900^{\mathrm{b}}$ & $1.814^{\mathrm{a}}$ & $1.075^{\mathrm{a}}$ & $0.474^{\mathrm{a}}$ & $2.738^{\mathrm{a}}$ \\
& \pm 0.213 & \pm 0.389 & \pm 0.204 & \pm 0.105 & \pm 0.911 \\
\hline
\end{tabular}

Values are means \pm standard deviation of triplicate samples.

Mean values bearing different superscript in the same column differ significantly $(\mathrm{P}<0.05)$.

Key: $\mathrm{CWZ}=$ coconut water and zobo wine, $\mathrm{CW}=$ coconut water wine, $\mathrm{CWH}=$ coconut water and honey wine, $\mathrm{CWHN}=$ coconut water and honey no yeast wine, $\mathrm{RW}=$ commercial red wine $($ control $), \mathrm{WW}=$ commercial white wine (control).

\section{H. Physicochemical Properties of Aged Table Wine Produced from Coconut Water and its Blends with Zobo and Honey}

Results for the physicochemical properties of Table wine produced from coconut water and its blends with Zobo and honey is presented in Table 5. Sugar content ranging from $11.00 \%-12.00 \%$, however, difference in sugar content of all the wine samples were not statistically significant $(\mathrm{P}>0.05)$. The sugar content was higher than $2.4 \%$ reported by [43] for 'Blaufrankish' commercial table wine. $\mathrm{pH}$ value ranged from $2.825-3.59$, the $\mathrm{pH}$ value of the coconut wine 
compared with those of the control except sample CWZ. The specific gravity of the coconut wine was significantly $(\mathrm{P}<0.05)$ higher than those of the control red and white wine. Total Acid and alcohol content ranged from $0.576-$ $0.921 \%$ and $5.87-11.50 \%$, respectively. The alcohol content of samples CWHN, CWH compared favourably with those of the control red and white wines. Alcohol content of $>5 \%$ was comparable with moderate grape wines [44]-[45]. According to [46] a good table wine must have alcohol content between 8 and 14\%. High alcohols are known to be important precursors for the formation of esters, which are associated with pleasant aromas [47]. High sugar content of more than $11 \%$ indicates that the wines were not dry table wines [9].

TABLE 5: PhysicochemicAl Properties of Aged TABle Wine PRODUCED FROM COCONUT WATER AND ITS BLENDS WITH ZOBO AND

\begin{tabular}{cccccc}
\multicolumn{6}{c}{ HONEY } \\
\hline \multirow{2}{*}{ Samples } & $\begin{array}{c}\text { Sugar } \\
(\%)\end{array}$ & $\mathrm{pH}$ & $\mathrm{SG}$ & $\begin{array}{c}\text { TA } \\
(\%)\end{array}$ & $\begin{array}{c}\text { ROH } \\
(\%)\end{array}$ \\
\hline \multirow{2}{*}{ CWHN } & $11.500^{\mathrm{a}}$ & $3.415^{\mathrm{ab}}$ & $1.011^{\mathrm{a}}$ & $0.717^{\mathrm{bc}}$ & $10.015^{\mathrm{c}}$ \\
& \pm 0.707 & \pm 0.120 & \pm 0.000 & \pm 0.047 & \pm 0.007 \\
$\mathrm{CWH}$ & $11.500^{\mathrm{a}}$ & $3.350^{\mathrm{ab}}$ & $1.009^{\mathrm{ab}}$ & $0.576^{\mathrm{c}}$ & $10.500^{\mathrm{b}}$ \\
& \pm 0.707 & \pm 0.071 & \pm 0.001 & \pm 0.004 & \pm 0.000 \\
$\mathrm{RW}$ & $11.000^{\mathrm{a}}$ & $3.590^{\mathrm{a}}$ & $0.996^{\mathrm{e}}$ & $0.703^{\mathrm{bc}}$ & $11.500^{\mathrm{a}}$ \\
& \pm 0.000 & \pm 0.014 & \pm 0.001 & \pm 0.021 & \pm 0.000 \\
WW & $11.500^{\mathrm{a}}$ & $3.375^{\mathrm{ab}}$ & $1.003^{\mathrm{c}}$ & $0.921^{\mathrm{a}}$ & $10.500^{\mathrm{b}}$ \\
& \pm 0.707 & \pm 0.035 & \pm 0.000 & \pm 0.014 & \pm 0.000 \\
$\mathrm{CW}$ & $12.000^{\mathrm{a}}$ & $3.195^{\mathrm{b}}$ & $1.000^{\mathrm{d}}$ & $0.853^{\mathrm{ab}}$ & $5.870^{\mathrm{e}}$ \\
& \pm 0.000 & \pm 0.007 & \pm 0.001 & \pm 0.094 & \pm 0.184 \\
$\mathrm{CWZ}$ & $12.000^{\mathrm{a}}$ & $2.825^{\mathrm{c}}$ & $1.007^{\mathrm{b}}$ & $0.690^{\mathrm{bc}}$ & $9.605^{\mathrm{d}}$ \\
& \pm 0.000 & \pm 0.035 & \pm 0.001 & \pm 0.051 & \pm 0.007 \\
\hline
\end{tabular}

Values are means \pm standard deviation of triplicate samples.

Mean values bearing different superscript in the same column differ significantly $(\mathrm{P}<0.05)$.

Key: $\mathrm{CWZ}=$ coconut water and zobo wine, $\mathrm{CW}=$ coconut water wine, $\mathrm{CWH}=$ coconut water and honey wine, $\mathrm{CWHN}=$ coconut water and honey no yeast wine, $\mathrm{RW}=$ commercial red wine $($ control), $\mathrm{WW}=$ commercial white wine (control), $\mathrm{SG}=$ specific gravity, $\mathrm{TA}=$ total acid, $\mathrm{ROH}=$ alcohol.

\section{Microbiological Quality of Aged Table Wine Produced from Coconut Water and its Blends with Zobo and Honey}

From Table 6 total bacteria count (TBC) ranged from 5.145 $\log _{10} \mathrm{CFU} / \mathrm{ml}$ to $6.230 \mathrm{Log}_{10} \mathrm{CFU} / \mathrm{ml}$ with sample $\mathrm{CWH}$ (coconut water and honey) wine given significantly higher value of $6.23 \log _{10} \mathrm{CFU} / \mathrm{ml}$. Total coliform (TCC) ranged from 4.602-5.301 $\log _{10} \mathrm{CFU} / \mathrm{ml}$ with samples $\mathrm{RW}$ (control red wine) and CWZ given significantly $(\mathrm{P}<0.05)$ higher and lower values respectively. Total L. bacillus count ranged from 4.875-5.431 $\log _{10} \mathrm{CFU} / \mathrm{ml}$ with no growth seen in sample CW. Total yeast count (TYC) ranged from 5.204$5.663 \mathrm{Log}_{10} \mathrm{CFU} / \mathrm{ml}$. these agreed with values reported by earlier researchers for water melon wine [35]. yeast count in samples $\mathrm{CWH}$ and $\mathrm{CW}$ were not significantly $(\mathrm{P}>0.05)$ different. Significantly $(\mathrm{P}<0.05)$ higher mould count of 4.954 $\log _{10} \mathrm{CFU} / \mathrm{ml}$ was noticed in the control white wine (WW). While no mould growth was seen in samples RW (control Red wine) and CWZ. This was probably due to better hygiene practice during the process of fermentation. Fermentation for production of beverages like wine depends on the ability and performance of the yeast to convert sugar contents of the substrates to alcohol and esters. The Coconut water, zobo and honey provided all the nutrients necessary in the completion of the fermentation, hence the fermenting 'must' was not induced with any artificial nutrient. The result of this work correlates with those of [48] that fermented water melon, banana and pineapple; and obtained quality wine product.

TABle 6: Microbiological Quality (LOG10CFU/ML) OF AgED TABLE WINE PRODUCED FROM COCONUT WATER AND ITS BLENDS WITH ZOBO

\begin{tabular}{cccccc}
\multicolumn{5}{c}{ AND HONEY } \\
$\begin{array}{c}\text { Wine } \\
\text { Samples }\end{array}$ & TBC & TCC & TLBC & TYC & TMC \\
\hline \multirow{2}{*}{ CWHN } & $5.934^{\mathrm{c}}$ & $5.079^{\mathrm{d}}$ & $5.431^{\mathrm{a}}$ & $\mathrm{NG}$ & $4.477^{\mathrm{d}}$ \\
& \pm 0.005 & \pm 0.000 & \pm 0.016 & & \pm 0.000 \\
CWH & $6.230^{\mathrm{a}}$ & $5.204^{\mathrm{b}}$ & $5.041^{\mathrm{b}}$ & $5.580^{\mathrm{b}}$ & $4.813^{\mathrm{b}}$ \\
& \pm 0.026 & \pm 0.027 & \pm 0.000 & \pm 0.000 & \pm 0.000 \\
$\mathrm{RW}$ & $5.732^{\mathrm{b}}$ & $5.301^{\mathrm{a}}$ & $4.954^{\mathrm{c}}$ & $5.204^{\mathrm{d}}$ & $\mathrm{NG}$ \\
& \pm 0.008 & \pm 0.000 & \pm 0.000 & \pm 0.027 & \\
WW & $5.940^{\mathrm{bc}}$ & $4.653^{\mathrm{e}}$ & $5.078^{\mathrm{b}}$ & $5.255^{\mathrm{c}}$ & $4.954^{\mathrm{a}}$ \\
& \pm 0.005 & \pm 0.010 & \pm 0.036 & \pm 0.024 & \pm 0.005 \\
CW & $5.145^{\mathrm{e}}$ & $5.114^{\mathrm{c}}$ & $\mathrm{NG}$ & $5.580^{\mathrm{b}}$ & $4.544^{\mathrm{c}}$ \\
& \pm 0.031 & \pm 0.000 & & \pm 0.011 & \pm 0.012 \\
CWZ & $5.982^{\mathrm{b}}$ & $4.602^{\mathrm{f}}$ & $4.875^{\mathrm{d}}$ & $5.663^{\mathrm{a}}$ & $\mathrm{NG}$ \\
& \pm 0.005 & \pm 0.000 & \pm 0.000 & \pm 0.000 & $\mathrm{NG}$ \\
\hline
\end{tabular}

Values are means \pm standard deviation of triplicate samples.

Mean values bearing different superscript in the same column differ significantly $(\mathrm{P}<0.05)$.

Key: $\mathrm{CWZ}=$ coconut water and zobo wine, $\mathrm{CW}=$ coconut water wine, $\mathrm{CWH}=$ coconut water and honey wine, $\mathrm{CWHN}=$ coconut water and honey no yeast wine, $\mathrm{RW}=$ commercial red wine $($ control $), \mathrm{WW}=$ commercial white wine (control), NG= No growth, $\mathrm{TBC}=$ total bacterial count, $\mathrm{TCC}=$ total coliform count, $\mathrm{TYC}=$ total yeast count, $\mathrm{TLBC}=$ total $\mathrm{L}$. bacillus count, $\mathrm{TMC}=$ total mold count

\section{J. Sensory Properties of Table Wine Produced from Coconut Water and its Blends with Zobo and Honey}

From the result in Table 7, Colour score for samples RW, WW, CW and CWZ were not significantly $(\mathrm{P}>0.05)$ different. The taste of sample $\mathrm{CW}$ compared favourably with those of the commercial red and white wines. The flavour of sample CWZ (coconut/zobo wine) also compared favourably with the commercial red and white wines. Clarify score ranged from 5.2 - 7.64 with sample CWZ receiving significantly $(\mathrm{P}<0.05)$ higher score of 7.64 . sample CWZ received equal overall acceptability with the commercial wines. Presence of undesired microbes during different stages of winemaking can produce volatile acidity, off-flavors and polysaccharide hazes, all of which can diminish the quality and acceptability of the final product [49].

TABle 7. Sensory Properties of TABle Wine Produced From COCONUT WATER AND ITS BLENDS WITH ZOBO AND HONEY.

\begin{tabular}{cccccc}
\hline Samples & Colour & Taste & Flavour & Clarity & $\begin{array}{c}\text { Overall. } \\
\text { Acceptability }\end{array}$ \\
\hline \multirow{2}{*}{ CWHN } & $5.16^{\mathrm{b}}$ & $4.68^{\mathrm{b}}$ & $4.96^{\mathrm{b}}$ & $5.20^{\mathrm{c}}$ & $5.08^{\mathrm{b}}$ \\
& \pm 1.772 & \pm 2.056 & \pm 1.881 & \pm 2.141 & \pm 1.754 \\
$\mathrm{CWH}$ & $5.64^{\mathrm{b}}$ & $7.00^{\mathrm{a}}$ & $5.16^{\mathrm{b}}$ & $5.88^{\mathrm{c}}$ & $5.44^{\mathrm{b}}$ \\
& \pm 1.680 & \pm 1.708 & \pm 1.841 & \pm 1.453 & \pm 1.530 \\
$\mathrm{RW}$ & $7.48^{\mathrm{a}}$ & $7.08^{\mathrm{a}}$ & $6.96^{\mathrm{a}}$ & $7.32^{\mathrm{ab}}$ & $7.28^{\mathrm{a}}$ \\
& \pm 1.503 & \pm 1.152 & \pm 1.306 & \pm 1.282 & \pm 0.843 \\
$\mathrm{WW}$ & 7.48 & $7.24^{\mathrm{a}}$ & $6.72^{\mathrm{a}}$ & $7.32^{\mathrm{ab}}$ & $7.24^{\mathrm{a}}$ \\
& $\mathrm{a} \pm 1.686$ & \pm 1.451 & \pm 1.720 & \pm 1.376 & \pm 1.091 \\
$\mathrm{CW}$ & $5.40^{\mathrm{a}}$ & $4.20^{\mathrm{a}}$ & $4.48^{\mathrm{b}}$ & $6.00^{\mathrm{bc}}$ & $5.16^{\mathrm{b}}$ \\
& \pm 2.273 & \pm 2.082 & \pm 2.002 & \pm 2.160 & \pm 1.930 \\
$\mathrm{CWZ}$ & $8.16^{\mathrm{a}}$ & $7.28^{\mathrm{a}}$ & $7.04^{\mathrm{a}}$ & $7.64^{\mathrm{a}}$ & $7.68^{\mathrm{a}}$ \\
& \pm 0.987 & \pm 1.646 & \pm 1.428 & \pm 0.952 & \pm 0.852 \\
\hline
\end{tabular}

Values are means \pm standard deviation of twenty-five responses.

Mean values bearing different superscript in the same column differ significantly $(\mathrm{P}<0.05)$.

Key: $\mathrm{CWZ}=$ coconut water + zobo wine, $\mathrm{CW}=$ coconut water wine, $\mathrm{CWH}=$ coconut water + honey wine, $\mathrm{RW}=$ commercial red wine $($ control $)$, $\mathrm{WW}=$ commercial white wine $($ control $), \mathrm{CWHN}=$ coconut water and honey no yeast wine. 


\section{CONCLUSION}

$\mathrm{pH}$ of 'must' from coconut water $(\mathrm{CW})$ reduced from 4.90 on day one to 2.40 on day 3 and remained constant up to day 6. Decrease in specific gravity of the fermented 'must' is due to increased metabolic activities leading to exhaustion of available nutrients with the concomitant production of alcohol. Sugar content of the 'must' was shown to decrease during fermentation. 'Must' from coconut/zobo (CWZ) and those from coconut water $(\mathrm{CW})$ did not record any coliform nor bacteria growth all through the period of fermentation. From the results, no coliform and bacterial growth were seen in fresh table wine produced from coconut water $(\mathrm{CW})$ and those produced from blends of coconut water and 'zobo' (CWZ), due to observed low $\mathrm{pH}$ value of 2.4 and 2.7 , respectively. Total coliform count in all the coconut wine samples were significantly $(\mathrm{P}<0.05)$ lower than those observed in the control (commercial red wine). There was no significant $(\mathrm{P}>0.05)$ difference in fat, protein, ash and carbohydrate content of the wine samples, including control (commercial red and white wine). The alcohol content of wine produced from coconut water and honey wine without yeast $(\mathrm{CWHH})$ and coconut water and Horney wine (CWH) were respectively $10.015 \%$ and $10.50 \%$, these compared favourably with those of the commercial red and white wines. High sugar content of all the coconut wine samples indicates that they were not dry table wines. Sample CWZ (coconut water/zobo wine) received equal overall acceptability with the commercial table wines. In conclusion, this study has shown that it is possible to produce wines from coconut water and its blends with good microbiological standard. Production of wine from these fruits could help reduce the level of post-harvest loss and increase variety of wines.

\section{REFERENCES}

[1] Steinkraus, K.H. (2002). Fermentation in World Food Processing. Compr. Rev. Food Sci. and Food Safety., 1, 23-27.

[2] Balogu, T.V.; Abdulkadir, A.; Ikegwu, M.T.; Akpadolu, B. and Akpadolu, K. (2016) Production and Sensory Evaluation of NonAlcoholic Wine from Sugarcane and Tiger Nut Blend Using Saccharomyces cerevisiae. Int. J. BioSci. Agric. Technol. 7, 7-14.

[3] Reddy, L. V and Reddy, O.V., S (2005) Production and characterization of wine from mango fruit (Mangiferaindica). World. Jr. Microbiol Biotechnol,21:1345-1350.

[4] Rivera-Espinoza, Y., Valdez-López, E. and Hernández-Sánchez, H. (2005) Characterization of a wine-like beverage obtained from sugarcane juice. World J Microbiol Biotechnol 21: 447-452.

[5] Kimball, D., (1991) Citrus processing: Quality Control and Technology, p. 2. AVI Publ. Van nostrand, Reinhold, New York.

[6] Akingbala, J.O. Oguntimein, G.B. Olunlade, B.A and Aina, J.O. (1992).Effects of pasteurization and packaging on properties of wine from over-ripe mango (Mangiferaindica) and banana (Musaacuminata) juices. Tropical Science, 34: 345-352.

[7] Joshi, V. K., Sandhu, D. K. and Thakur, N. S., (2000) Fruit Based Alcoholic Beverages. Biotechnology: Food Fermentation, Vol. II. V. K. Joshi and Ashok Pandey (eds), pp. 647-732.

[8] Ohoke, F.O.and Igwebike, O.C. D (2017). Physico-Chemical Properties and Sensory Evaluation of Wine Produced from Tiger Nut (Cyperusesculentus) International Journal of Chem Tech Research,10(12): 155-164.

[9] Shrikant, B. S. Thakor, N.J. and Divate, A.D. (2014) Fruit Wine Production: A Review. Journal of Food Research and Technology 2(3): 93-100.

[10] Thankappan, G and Anitha, P. (2018). Effect of sources of coconut water and acidulants on physico chemical properties of nata-de-coco. Journal of Tropical Agriculture 56 (2): 206-207.
[11] Bourdeix R, Konan JL and N'Cho YP (2005). Coconut: a guide to traditional and improved varieties, Ed. Diversiflora, Montpellier, France. Page 104

[12] Polemer, M. Cuarto1. and Ronie, F. (2017). Magsino2 Mindoro Development of Young Coconut (Cocosnucifera) Wine State College of Agriculture and Technology - Calapan City Campus, Mindoro, Philippines polemath@yahoo.com Asia Pacific Journal of Multidisciplinary Research Vol. 5 No.2, 89-93. Part II P-ISSN 23507756 E-ISSN 2350-8442 www.apjmr.com.

[13] Satheesh, N and Prasad, N.B.L. (2013). Production of fermented coconut water beverages. Asian Journal of Food and Agro-Industry, 6(05), 281-289.

[14] Golowczyc, M.A., Silva, J., Teixeira, P. and Abraham, A.G. (2011). Cellular injuries of spray-dried Lactobacillus spp. isolated from kefir and their impact on probiotic properties. International journal of food microbiology 144(3):556-60.

[15] Gupta, J.K. and Sharma, R. 2009. Production Technology and quality characteristics of mead and fruit-honey wines. Nat. Prod. Radiance, 8, 345-355.

[16] Oboh, G. and Elusiyan, C. A. (2004). Nutrient Composition and Antimicrobial Activity of Sorrel Drinks (soborodo). Journal of Medicinal Food. 7(3):340-342.

[17] Muhammed, F.S. and Umar, B. M. (2007). Production and organoleptic assessment of a sweetened Sorrel drink. Namoda TechScope- A. Journal of Applied Science and Technology. 7: 7-13.

[18] [18] Braide, W., Oranusi, S and Peter-Ikechukwu, A. I. (2012). Perspectives in the hurdle techniques in the preservation of a nonalcoholic beverage, Zobo. African Journal of Food Science and Technology. 3:46-52.

[19] [19] Kocher SG, Pooja (2011) Status of wine production from guava (Psidium guajava L.): a traditional fruit of India. Afr J Food Sci 5(16):851-860

[20] Okoro,C.E. (2007). Production of red wine from roselle (Hibiscus sabdariffa) and pawpaw (Carica papaya) using palm-wine yeast (Saccharomyces cerevisiae). Nigerian Food Journal, 32, 67-77.

[21] AOAC (2012) Association of Official Analytical Chemists. Official Methods of Analysis, 19th Edition Washington, DC USA.

[22] Muchtaridi, M., Musfiroh, I., Hambali, N. N., Indrayati, W. (2012). Determination of alcohol of fermented black tape ketan based on different fermentation time using specific gravity, refractive index and CG-MS methods. Journal of Microbiology, Biotechnology and Food Sciences, 2(3): 933- 946.

[23] Harrigan, W.F. (1998). Laboratory methods in Microbiology Academics Press, Califonia, USA.

[24] Cheesbrough, M. (2002). Water-related diseases and testing of water diseases lies in District Laboratory Practice in Tropical Countries. Part 2 (LP. Ed). Cambridge University Press, Cambridge, U.K. Pp 143-157

[25] Iwe, M.O. (2002) Handbook of sensory methods and analysis. Enugu, Nigeria: Rojoint Communications. Services Limited; 2002.p 14.

[26] Idise O. E., 2011 Studies on Wine Production from Coconut (cocos nucifera) Journal of Brewing and Distilling vol 2(5): 69-74.

[27] Ezemba, C. C. and Archibong, E. J. (2017). Comparative Studies of Wine Produced from Coconut (Cocos Nucifera) and Mango Fruit (Mangiferaindica) using Yeast Isolated from Palm Wine. International Journal of Research in Pharmacy and Biosciences, 4,8, 44-49.

[28] Awe, S. (2011). Production and Microbiology of Pawpaw (Carica papaya L) Wine. Current Research Journal of Biological Sciences 3(5): 443-447.

[29] Berry, C.J.J., (2000). First Steps in Wine Making. Published by G.W. Kent, Inc. 3667 Morgan Road, Ann Arbor M I 48108, 235

[30] Okeke, B. C, Agu, K. C., Uba, P. O., Awah, N. S., Anaukwu C. G., Archibong, E. J., Uwanta, L. I., Ogodo, A. C., Ubogu, O. C. and Ezeonu, C. S. (2015). Production of Mixed Fruit (Pawpaw, Banana and Watermelon) Wine using Saccharomycescerevisiae isolated from Palm Wine. Springer Plus, 4: 683.

[31] Sahu UC, Panda SK, Mohapatra UB. and Ray RC. (2012) Preparation and evaluation of wine from tendu (Diospyrosmelanoxylon L) fruits with antioxidants. Int J Food Fermentation Technol. 2(2):167-178.

[32] Ray R. C., Panda S. K., Swain M. R.andSivakumar S. P (2012) Proximate composition and sensory evaluation of anthocyanin-rich purple sweet potato (Ipomoea batatas L.) wine. Int J Food Sci Technol. 1365-2621.doi:10.1111/j.

[33] Obaedo, M.E, Ikenebomeh, M.J (2009) Microbiology and production of banana (Musa sapientum) wine. Nig J Microbiol 23: 1886-1891.

[34] Aminu Z., Yabaya A., Mohammed, S.S.D. and Bobai, M. (2018). Quality Assessment of Water Melon (Citruluslanatus) Wine 
Produced Using Saccharomyces cerevisiae Isolated from Palm Wine. Journal of Biomaterials, 2(2): 65-73.

[35] Mountney, G. J. and Gould, W. A. (1988). Practical Food Microbiology and Technology. AVI Books, Van Nostrand Reinhold Company, New York, USA.

[36] Frazier, W. C and Westhoff (1991). Food microbiology. ${ }^{\text {rd }}($ Ed) mc Gram Hill pub.co. New Delhi Tata Nutrient utilization profile of Saccharomyces Cerevisiae from palm wine in tropical fruit fermentation. Antonie Van Leeuwenhoek 86:235-239.

[37] Adams, M.R. and Moss, M. O. (1995). Food Microbiology. The Royal Society of Chemistry Books, Van Nostrand Reinhold Company, New York, USA.

[38] ICMSF (1996). Toxigenic fungi: Aspergillus. In: Microorganisms in Foods. 5. Characteristics of Food Pathogens Academic Press, London, 347-381.

[39] Garbutt, J. (1997). Essentials of Food Microbiology; Arnold Publishers.Pp103 - 245.

[40] Inuwa, H. M., Aina, V. O., Baba, G., Aimola, I., Veronica, T. (2011). Determination of Differences in Nutrient Composition of Citrullusvulgaries (Water Melon) Fruits after Plucking. British Journal of Dairy Sciences, 2(2): 27-30.

[41] Awe, S., Eniola, K.I.T. and Kayode-Ishola, T. M. (2013). Proximate and Mineral Composition of locally produced pawpaw and banana wine. American Journal of Research communication, 1 (12) 388397.

[42] Awe, S and Nnadoze, S. N. (2015). Production and Microbiological Assessment of Date Palm (Phoenix dactylifera L.). British Microbiology Research Journal, 8(3): 480-488.

[43] Ayogu TE (1999) Evaluation of the performance of yeast isolate from Nigeria palm wine in wine production from pineapple fruits. Bio resource Technology 69:189-190.

[44] Okonkwo, W.O, Okotore, R.O, Osuntoki, A.A (2005) The Alcoholic fermentation efficiency of indigenous yeast strains of Different origin on orange juice. Afri J Biotechnol 4: 1290-1296.

[45] Michael, P, (2000). Foods of the Gods: part 1 - Wine in Ancient Egypt. http:// www.touregypt.net/Egypt-Retrieved (16/7/2018). Morgan Road, Ann Arbor M I 48108, pp: 235.

[46] Clement-Jimenez JM, Mingorance-Cazoria L, Martinez-Rodriguez S, Herasvazquez FJL, Rodriguez-Vico F (2005) Influence of sequential yeast mixtures in wine fermentation. Internal Journal of Microbiology, 98:301-308.

[47] Omoya, F. O, and Akharaiyi, F. C. (2008). Studies on Qualitative and Quantitative Characterization of Alcoholic Beverages from Tropical Fruits. Research Journal of Microbiology, 3: 429-435.

[48] Sponholz, W. (1993). Spoilage by wine microorganisms. In Fleet, G.H. (ed), Wine Microbiology and Biotechnology, Harwood Academic Publishers, Switzerland, pp 395-420. 